\title{
A Laboratory Study of the Effect of Temperature on Densities and Viscosities of Binary and Ternary Blends of Soybean Oil, Soy Biodiesel and Petroleum Diesel Oil
}

\author{
Oluwafunmilayo A. Aworanti, Samuel E. Agarry", Ayobami O. Ajani \\ Biochemical Engineering and Biotechnology Research Laboratory, Department of Chemical Engineering, \\ Ladoke Akintola University of Technology, Ogbomoso, Nigeria \\ Email: "sam_agarry@yahoo.com
}

Received April 20, 2012; revised May 25, 2012; accepted June 6, 2012

\begin{abstract}
The depletion of world petroleum reserves and the increased environmental concerns have stimulated the search for alternative sources for petroleum based fuel. The possibility of using vegetable oils as fuel has been recognized, however, due to its high viscosities and low volatilities makes it inefficient for most combustion engines and thus the need to get them chemically altered or transesterified to obtain fatty alkyl esters of the oil (biodiesel). In this study, binary and ternary blends of biodiesel were produced and the effect of temperature on their viscosity and density was investigated. Biodiesel was produced from soybean oil by transesterification of the oil with methanol using potassium hydroxide as a catalyst at a temperature of $60^{\circ} \mathrm{C}$ in a batch reactor. Binary and ternary blends of the soy-biodiesel were prepared with soy bean oil and petroleum diesel fuel, respectively. Viscosities and densities of the binary and ternary blends were measured at different temperatures of $20^{\circ} \mathrm{C}$ to $90^{\circ} \mathrm{C}$ as to determine the effect of temperature on viscosities and densities of the blends. The properties of the soy-biodiesel produced were compared with ASTM standard and found to be within the limits. The results show that the viscosities and densities of both the binary and ternary blends are temperature dependent. The viscosities of binary and ternary blends decreased nonlinearly with temperature, while their densities decreased linearly with temperature. The variation of temperature with viscosity and density of the blends was correlated and the polynomial equation offered the best correlation between temperature and viscosity, while linear equation gave the best correlation between temperature and density. In conclusion, the efficiency of binary and ternary blends of biodiesel in combustion engines is dependent on the viscosity and density of the blends which are invariably temperature dependent.
\end{abstract}

Keywords: Densities; Viscosities; Batch Reactor; Diesel Fuel; Soy-Biodiesel; Vegetable Oil

\section{Introduction}

The depletion of world petroleum reserves and the increased environmental concerns have stimulated the search for alternative sources for petroleum based fuel, including diesel fuels. With increasing demand on the use of fossil fuels, stronger threat to clean environment is being posed as burning of fossil fuels is associated with emissions like $\mathrm{CO}_{2}, \mathrm{CO}, \mathrm{SO}_{2}, \mathrm{NO}_{2}$ and particulate matter which are currently the dominant global source of emissions. The harmful exhaust emissions from the engines, rapid increase in the prices of petroleum products, the increasing fuel prices and uncertainties of their supply have jointly created renewed interest among researchers to search for suitable alternative fuels. There is therefore a growing substitution of fossil fuels with fuel derived from renewable resources. This substitution requires in-

${ }^{*}$ Corresponding author. creased efforts in the research and development of producing these fuels from different renewable resources. This is the case for biodiesel (alkyl esters) production from vegetable oils [1]. The use of vegetable oil as an alternative fuel had been under study as far back as 1979 [2]. Vegetable oil based fuels are sustainable sources of fuel because as long as they are produced in an ecologically sustainable way, they will not run out. Depending upon the climate and soil conditions, different countries are looking for different types of vegetable oils as substitutes for diesel fuels. For example, soybean oil in the US, rapeseed and sunflower oils in Europe and palm oil in Southeast Asia are being considered [3]. The possibility of using vegetable oils as fuel has been recognized since the beginning of diesel engines.

In 1911, Rudolph Diesel presented an engine based on compression ignition; the diesel engine. At that time, there was no specific fuel to feed this engine and 
groundnut oil was used [4]. There have been many problems associated with using vegetable oils directly in diesel engines; coking and trumpet formation on the injectors to such an extent that fuel atomization does not occur properly or is even prevented, decrease in power output and thermal efficiency of the engines, carbon deposits, oil ring sticking; thickening or gelling of the lubricating oil as a result of contamination by vegetable oils [2,5]. Vegetable oils also have high viscosity (11 17 times higher than diesel fuel) and lower volatility that results in carbon deposits in engines due to incomplete combustion. However, the high viscosities and low volatilities of this oil have been reported to make them inefficient for most combustion engines [6] and thus the need to get them chemically altered or transesterified to obtain alkyl esters of the oil (biodiesel). Besides all the above, vegetable oils contain polyunsaturated compounds.

Transesterification has been tested to be one of the chemical modifications to overcome these problems caused by the use of vegetable oils. The transesterification reduces the molecular weight of vegetable oils and also reduces the viscosity and improves the volatility. The product of the reaction is biodiesel, glycerol, alcohol and catalyst. Biodiesel is produced through a transesterification reaction [7]. In this reaction, with the presence of a catalyst, triglycerides react with an alcohol producing a mixture of fatty acid alkyl esters (FAAE) and glycerol [8]. The stoichiometric reaction requires 1 mole of triglycerides and 3 mole of alcohol. However, excess alcohol is required to drive the reaction close to completion $[9,10]$. Biodiesel extracted from vegetable oil is one of such renewable alternative under consideration, and because of its closer properties to diesel fuel, biodiesel fuel (fatty acid methyl ester) from vegetable oil is considered as the best candidate for diesel fuel substitute in diesel engine [11]. Biodiesel can therefore be technically defined as the alkyl ester of fatty acids, made by the transesterification of oils or fats, from plants or animals, with short chain alcohols such as methanol and ethanol.

The catalysts used for transesterification could be classified as homogeneous and heterogeneous catalysts Homogeneous catalysts are alkalis such as hydroxides $(\mathrm{NaOH}, \mathrm{KOH}$, carbonates and corresponding sodium and potassium alkoxides) [12] and acids like sulphuric acid and hydrochloric acid; while heterogeneous catalysts include among others tungsten oxides, resins and sulphonated saccharides $[7,13]$. However, in the last few years, the studies of the enzymatic catalyzed production of biodiesel have shown significant progress [14-16]. The main problem of the enzyme catalyzed process is the high cost of the lipases (enzyme) used as catalyst [16]. At industrial scale, alkaline catalysis is usually used in biodiesel production from edible oil.

The properties of biodiesel are close to conventional diesel and hence become a strong candidate to replace the diesel fuel [11]. Its advantages over conventional diesel fuels are its lower toxicity, high biodegradability, substantial reduction in $\mathrm{SO}_{\mathrm{x}}$ emissions, considerable reduction in carbon monoxide (CO), polyaromatic hydrocarbons, smoke and particulate matter [12]. In addition, biodiesel has a high heat value, high oxygen content (10\% $11 \%$ ) [17] and does not contribute to global warming due to its carbon closed cycle [1]. Biodiesel has substantially different properties than vegetable oils and result in better engine performance. However, there are some drawbacks of biodiesel like higher cost and cold flow properties. Among the possible raw materials for the production of biodiesel, the use of rapeseed oil, canola oil, soybean oil, palm kernel oil, coconut oil, cotton seed oil and citrus seeds oil has been investigated [5,18-22]. Several studies on binary blends of biodiesel and diesel fuel or vegetable oils have been investigated, but not much has been done on ternary blends of biodiesel, diesel fuels and vegetable oils.

Viscosity is one of the most important physical properties of a fluid system [23]. Viscosity changes with shear rate, temperature, pressure, moisture, and concentration; all these changes can be modelled by equations $[24,25]$. Studies on viscosity have been performed on pineapple juice, vegetable oil, etc. [26]. However, there is a dearth of information on the effect of temperature on the viscosity and density of binary and ternary blends of biodiesel oil. Modelling of the temperature effect on the dynamic viscosity of oils is important and has been investigated by some researchers [25,27-29]. However, modelling of the effect of temperature on viscosity and density of biodiesel is rarely reported. Therefore, the main objective of this study was to produce soy-biodiesel from soybeans oil and the effect of temperature on the viscosities and densities of binary and ternary blends of this biodiesel. Furthermore, polynomial and/or linear dependence of dynamic viscosity and density of soy biodiesel and its blends on temperature was determined.

\section{Materials and Methods}

\subsection{Materials}

Refined soybeans oil (being a product of UAC Foods, Nigeria) was purchased from a local market in Lagos, Nigeria. Methanol (99\% purity) and potassium hydroxide being products of Merck Dam were purchased from a chemical store in Lagos, Nigeria. The equipments used for the experiments are: VT 550 rotating viscometer, flash point analyzer, 50ml density bottle, mass balance, mechanical stirrer (overhead stirrer fixed with a stainless steel propeller) and electromagnetic stirrer, water bath, thermometer, $1000 \mathrm{ml}$ jacketed glass, electric burner, 
reflux condenser and oven.

\subsection{Methods}

\subsubsection{Methanolysis of Soybean Oil: Production of Biodiesel}

The production of biodiesel was carried out in a batch reactor. The reactor consisted of a $1 \mathrm{~L}$ jacketed glass, electrical stirrer fitted with a stainless steel propeller(for thorough mixing/agitation), thermometer and a reflux condenser(for preventing the methanol from escaping out of the reactor) since methanol boils at $65^{\circ} \mathrm{C}$ in a hot water bath to control the reaction temperature. Transesterification reaction of soybean oil was carried out with potassium hydroxide $(1 \%)$. Potassium hydroxide (mass fraction 1\%) was dissolved in $46 \mathrm{ml}$ of methanol using the magnetic stirrer to make a homogenous mixture. Soybeans oil was measured (167.04 g), pre-heated to a temperature of $60^{\circ} \mathrm{C}$ and poured into the reactor. The homogenous mixture of methanol and potassium hydroxide was then poured into the reactor containing the soybean oil. The electrical stirrer was set into motion and the reaction was carried out at a temperature of $60^{\circ} \mathrm{C}$ for 1 hour. The mixing mole ratio of methanol to oil used was 4:1. At the end of 1 hour, the oil has been effectively transesterified; two layers were formed, an upper layer of amber yellow colour [0.5 ASTM] was suspected to be biodiesel while the lower layer of a wine//oxbow lake colour [2.5 ASTM] was suspected to be glycerol. The dark colour of the glycerol was due to the presence of excess catalyst in the lower layer. The suspected biodiesel was separated, washed with warm water and then heated above $65^{\circ} \mathrm{C}$ (boiling point of methanol) to remove any excess methanol in it. The suspected biodiesel was then analysed for its fuel properties.

\subsubsection{Binary and Ternary Blending of Soy Biodiesel}

The biodiesel produced from soybean oil was blended with petroleum diesel oil and soybean oil, respectively, using direct blending method. The blends were prepared according to the stated measured percentages (Table 1) using a beaker, electrical stirrer with a stainless steel propeller and mixed at room temperature for 1 hour. For example, the blend with a mixture of $30 \%$ biodiesel and $70 \%$ petroleum diesel is referred to as B30 blend.

\subsubsection{Analyses}

The suspected biodiesel was then analysed for some properties such as dynamic viscosity, density, cloud point, pour point, flash point and colour, respectively. Density and viscosity measurements were made according to ASTM standard D1298 and D445, respectively. Dynamic viscosity $14^{\circ} \mathrm{C}$ was measured using a Bookfield viscometer. Flash point was measured using the flash point analyzer, colour was measured using the colour meter, and pour point and cloud point were measured using ice packs, test tubes and transparent cooling chamber. The pour and flash points were determined following ASTM standard D297, D25100-8 and D56, respectively.

1) Determination of Viscosity

The viscosities of the blends were measured using VT 550 rotating viscometer by putting the blend in a beaker while the beaker was put in a water bath (to control the temperature of the mixture) on an electric burner. Temperatures were increased at $10^{\circ} \mathrm{C}$ interval from $20^{\circ} \mathrm{C}$ to $90^{\circ} \mathrm{C}$ and readings of viscosities were recorded. Thermometer was placed in both the water bath and blend mixture to ensure accuracy in temperature readings. The readings of viscosities were done in triplicates and the average values were used.

2) Determination of Density

The densities of the blends were taken from a temperature range of $20^{\circ} \mathrm{C}$ to $90^{\circ} \mathrm{C}$. The blends were put in a $50 \mathrm{ml}$ density bottle and weighed on a mass balance. The densities were then obtained as given in Equation (1). The densities were measured in triplicates and the average values were used.

$$
D=\frac{\left(M_{B L}-M_{B}\right)}{V_{L}}
$$

where $D$ is density of liquid $\left(\mathrm{g} / \mathrm{cm}^{3}\right) ; M_{B L}$, the mass of bottle and liquid (g); $M_{B}$, the mass of bottle only and $V_{L}$ is the volume of the liquid $\left(\mathrm{cm}^{3}\right)$.

\section{Results and Discussion}

\subsection{Properties of the Soy-Biodiesel}

The physical properties of the suspected biodiesel (viscosity, density, cloud point, pour point, flash point and colour) was determined and compared with the international standard for biodiesel as shown in Table 2. It could be seen from Table 2 that the fuel properties of the soy-biodiesel are within the value range limits specified by international standard for biodiesel.

\subsection{Dynamic Viscosities and Densities of Blends}

Viscosity is a measure of the internal flow resistance of a liquid (i.e. the thickness of the oil) and this constitutes an intrinsic property of vegetable oils. This is determined by measuring the amount of time taken for a given measure of oil to pass through an orifice of a specific size. Viscosity affects injection lubrication and fuel atomization [30]. The higher is the viscosity, the greater is the tendency for the fuel to form engine deposits [31].

The variations in viscosity of different binary blends of soybean oil and petroleum diesel with temperature are shown in Figure 1. The result shows that for each of the 
Table 1. Preparation of binary and ternary blends of soy biodiesel.

\begin{tabular}{|c|c|c|}
\hline Run & Composition of Blends & Volume of Mixtures \\
\hline 1 & P100 & 100 ml petroleum diesel (PD) \\
\hline 2 & $95 \% \mathrm{PD}+5 \% \mathrm{SO}$ & $95 \mathrm{ml}$ petroleum diesel $+5 \mathrm{ml}$ soy bean oil (SO) \\
\hline 3 & $90 \% \mathrm{PD}+10 \% \mathrm{SO}$ & $90 \mathrm{ml}$ petroleum diesel $+10 \mathrm{ml}$ soy bean oil \\
\hline 4 & $80 \% \mathrm{PD}+20 \% \mathrm{SO}$ & $80 \mathrm{ml}$ petroleum diesel $+20 \mathrm{ml}$ soy bean oil \\
\hline 5 & $70 \% \mathrm{PD}+30 \% \mathrm{SO}$ & $70 \mathrm{ml}$ petroleum diesel $+30 \mathrm{ml}$ soy bean oil \\
\hline 6 & B100 & $100 \mathrm{ml}$ soy biodiesel (SBD) \\
\hline 7 & B5 & $95 \mathrm{ml}$ petroleum diesel $+5 \mathrm{ml}$ soy biodiesel \\
\hline 8 & B10 & $90 \mathrm{ml}$ petroleum diesel $+10 \mathrm{ml}$ soy biodiesel \\
\hline 9 & B20 & $80 \mathrm{ml}$ petroleum diesel $+20 \mathrm{ml}$ soy biodiesel \\
\hline 10 & B30 & $70 \mathrm{ml}$ petroleum diesel $+30 \mathrm{ml}$ soy biodiesel \\
\hline 11 & $95 \% \mathrm{PD}+3.5 \% \mathrm{SBD}+1.5 \% \mathrm{SO}$ & $95 \mathrm{ml} \mathrm{PD} \mathrm{+} 3.5 \mathrm{ml} \mathrm{SBD} \mathrm{+} 1.5 \mathrm{ml} \mathrm{SO}$ (Ternary) \\
\hline 12 & $90 \% \mathrm{PD}+7 \% \mathrm{SBD}+3 \% \mathrm{SO}$ & $90 \mathrm{ml} \mathrm{PD}+7 \mathrm{ml} \mathrm{SBD}+3 \mathrm{ml} \mathrm{SO}$ \\
\hline 13 & $80 \% \mathrm{PD}+14 \% \mathrm{SBD}+6 \% \mathrm{SO}$ & $80 \mathrm{ml} \mathrm{PD}+14 \mathrm{ml} \mathrm{SBD}+6 \mathrm{ml} \mathrm{SO}$ \\
\hline 14 & $70 \% \mathrm{PD}+21 \% \mathrm{SBD}+9 \% \mathrm{SO}$ & $70 \mathrm{ml} \mathrm{PD}+21 \mathrm{ml} \mathrm{SBD}+9 \mathrm{ml} \mathrm{SO}$ \\
\hline
\end{tabular}

Table 2. Measured properties of soy bean oil, soy biodiesel and petroleum diesel as against ASTM standard.

\begin{tabular}{|c|c|c|c|c|c|}
\hline Properties & Soy bean oil & Soy bean biodiesel & Petroleum diesel & $\begin{array}{l}\text { Standard for } \\
\text { petroleum diesel }\end{array}$ & $\begin{array}{l}\text { Standard for } \\
\text { biodiesel (EN 14214) }\end{array}$ \\
\hline Dynamic viscosity at $28^{\circ} \mathrm{C}$ & 33.33 & 6.809 & 4.024 & $1.3-4.1$ at $40^{\circ} \mathrm{C}$ & $3.08-4.4$ at $40^{\circ} \mathrm{C}$ \\
\hline Density $\left(\mathrm{g} / \mathrm{cm}^{3}\right)$ & 0.9068 & 0.8712 & 0.8354 & $0.82-0.86$ & $0.86-0.90$ \\
\hline Water content (\%) & 0.03 & 0.00 & - & - & - \\
\hline Flash point & 170 & 102 & 69 & $60-80$ & $>101$ \\
\hline Cloud point & - & -1 & -5 & - & -2 to 12 \\
\hline Pour point & -0.4 & -6 & -9 & -35 to -15 & -15 to 10 \\
\hline Colour & 0.5 & 0.5 & 2 & 2 & - \\
\hline
\end{tabular}

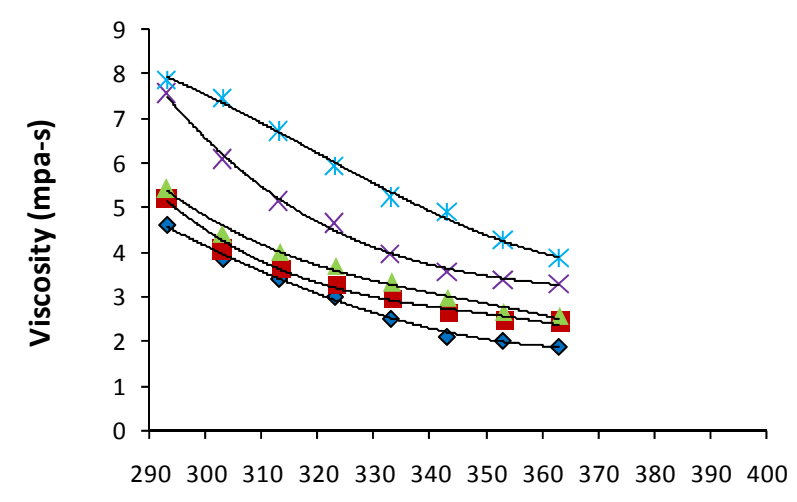

Temperature (K)

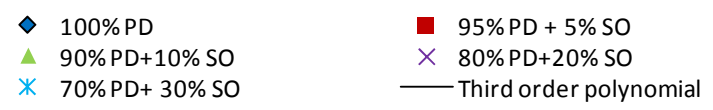

Figure 1. Effect of temperature on viscosities of binary blends of soybean oil with petroleum diesel oil at different volume fraction. 
binary blends with different percent mixture composition, the viscosity decreased non-linearly with temperature. Also at a fixed temperature, there was a decrease in viscosities of the soybean oil and petroleum diesel blend as the percent volume of petroleum diesel in the mixture increases (i.e. the blend with $70 \%$ petroleum diesel and $30 \%$ soybean oil has the least viscosity). The viscosity for this blend is moderately high at low temperature (varying from 7.843 at $20^{\circ} \mathrm{C}$ to 1.845 at $90^{\circ} \mathrm{C}$ ) and decreased at high temperature. Nevertheless, manufacturers of diesel engines will not accept blends with viscosities that fall below the range limit of viscosity for diesel fuel.

The viscosities of each binary blend of soy-biodiesel and petroleum diesel of different percent mixture composition decreased non-linearly with temperature as shown in Figure 2. The viscosity for each of the different blend was very high at low temperature and decreased as the temperature increased. Also at a fixed temperature, there was a decrease in viscosities of soy-biodiesel and petroleum diesel blend as percent volume of petroleum diesel in the mixture increased. The viscosity for this blend falls within the limit of tested viscosity of blends for diesel engines used across the globe (varying from 5.226 at $20^{\circ} \mathrm{C}$ to 1.845 at $90^{\circ} \mathrm{C}$ ).

Figure 3 shows the variation in viscosity of ternary blends of soybean oil, soy-biodiesel and petroleum diesel, of different percent volume mixture composition with temperature. From the figure, it could be seen that viscosity was high at low temperature, however, decreased as the temperature increased. That is, viscosity decreases nonlinearly with temperature. Also at a fixed temperature, there was a decrease in viscosities of the ternary blend as the percent volume of petroleum diesel in the mixture increases. The viscosity for this ternary blend falls within reasonable limit of tested viscosity of blends that can be used for diesel engines used across the globe (varying from 5.508 at $20^{\circ} \mathrm{C}$ to 2.264 at $90^{\circ} \mathrm{C}$ ). This was not far from the viscosity variation for the binary blend of bio- diesel and petroleum diesel. Further investigation by practical testing of this blend on diesel engines shall be carried out in our next research work to ascertain if it will possible to use it on diesel engines without much modifications.

Figures $\mathbf{4}$ and $\mathbf{5}$ show the variations in densities of binary blends of soybean oil and soy-biodiesel; soybean oil and petroleum diesel fuel; and soy-biodiesel and petroleum diesel fuel, respectively, (all of different percent volume mixture composition) with temperature. Density or specific gravity has been described as one of the most basic or important parameters of fuel as certain performance indicators such as heating value and cetane number are correlated with it $[5,30,32]$. Compression ignition engines are designed to inject fuel into the combustion chamber by volume rather than mass and it is desirable to maintain diesel density within a tight tolerance to achieve optimal air to fuel ratios. The results from each of Figures $\mathbf{4}$ and $\mathbf{5}$ revealed that for each of the binary blends, densities were high at low temperature and decreases as the temperature increased. That is, densities decrease non-linearly with temperature. Also at a fixed temperature, there was decrease in densities of soybean oil and soy-biodiesel blends as the percent volume of soy-biodiesel in the mixtures increased. This decrease in densities was also observed for the soybean oil and petroleum diesel blend, and soy-biodiesel and petroleum diesel blend as the volume fraction of petroleum diesel increased in the mixtures.

Figure 6 also shows the temperature and composition dependent behavior of the densities of ternary blends of soy-biodiesel, soybean oil and petroleum diesel fuel. The results as revealed in the figure were similar to those obtained for the binary blends. However, the densities of binary blend of biodiesel and petro diesel falls within range limits for international standard of biodiesel and the ternary blends show density closely related to that of biodiesel. Further investigation will ascertain its suitability for use.

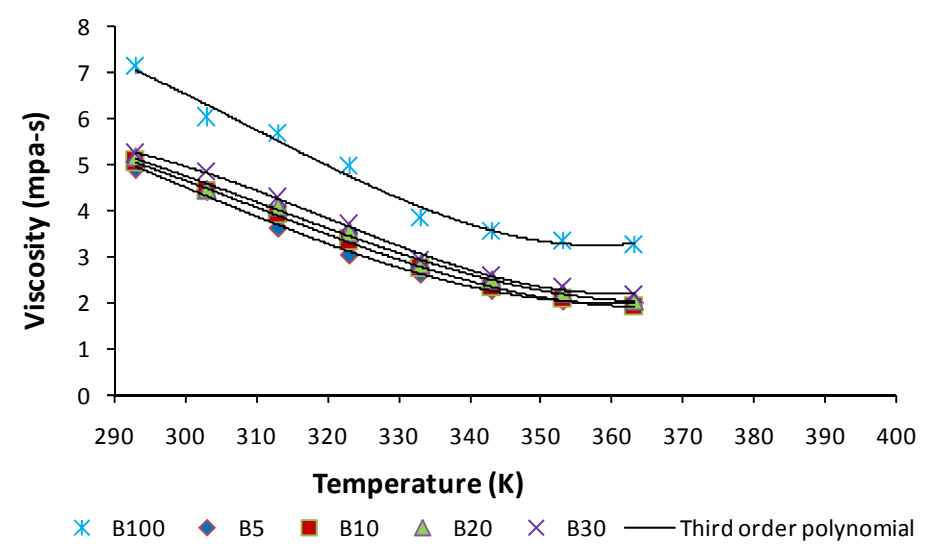

Figure 2. Effect of temperature on viscosities of binary blends of soy biodiesel with petroleum diesel oil at different volume fractions. 


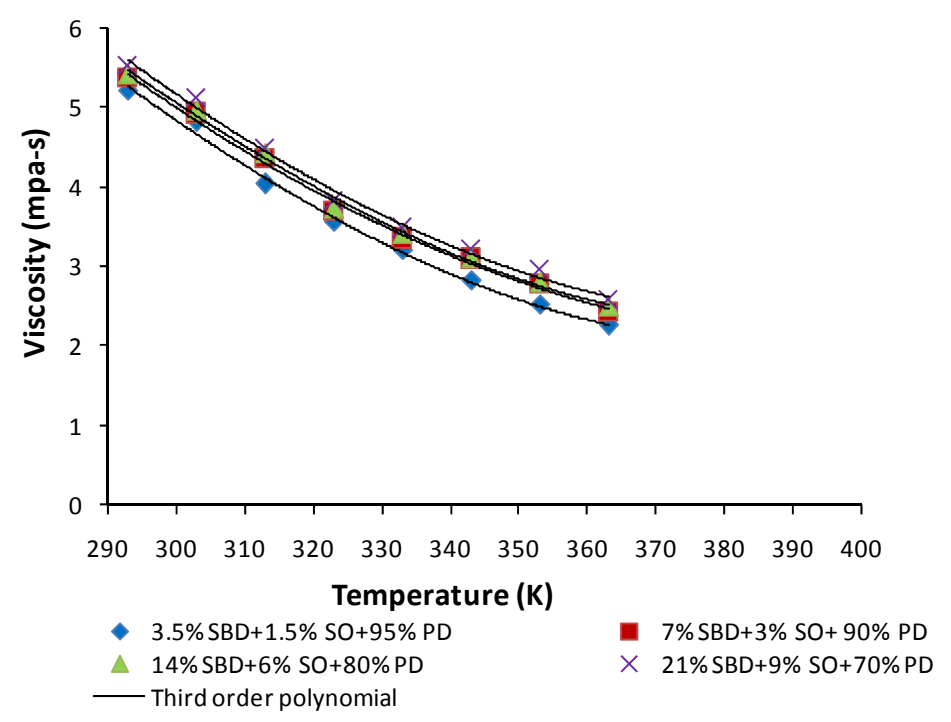

Figure 3. Effect of temperature on viscosities of ternary blends of soy biodiesel With soybean oil and petroleum diesel oil at different volume fractions.

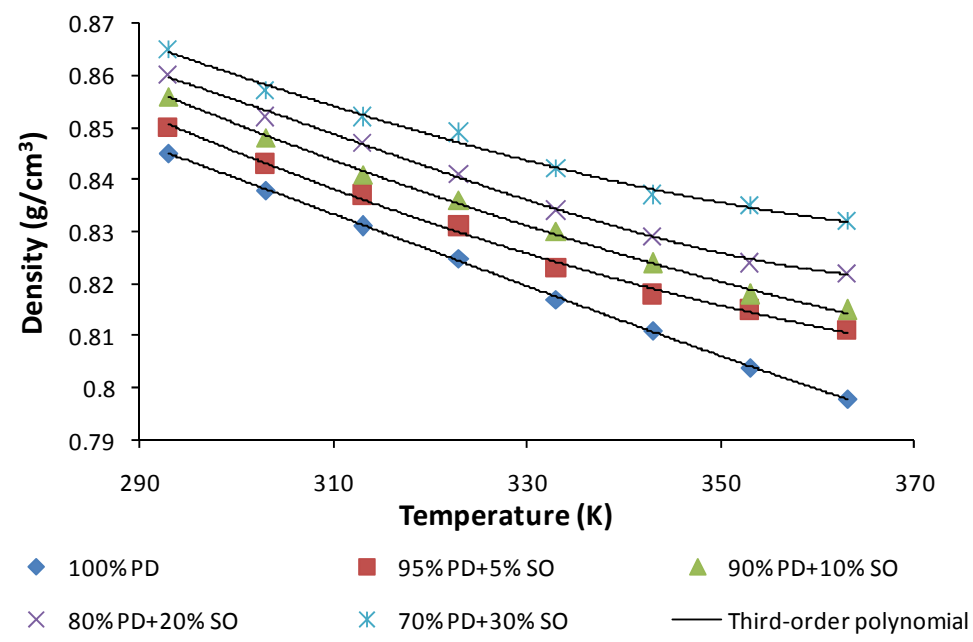

Figure 4. Effect of temperature on densities of binary blends of soybean oil with petroleum diesel oil at different volume fractions.

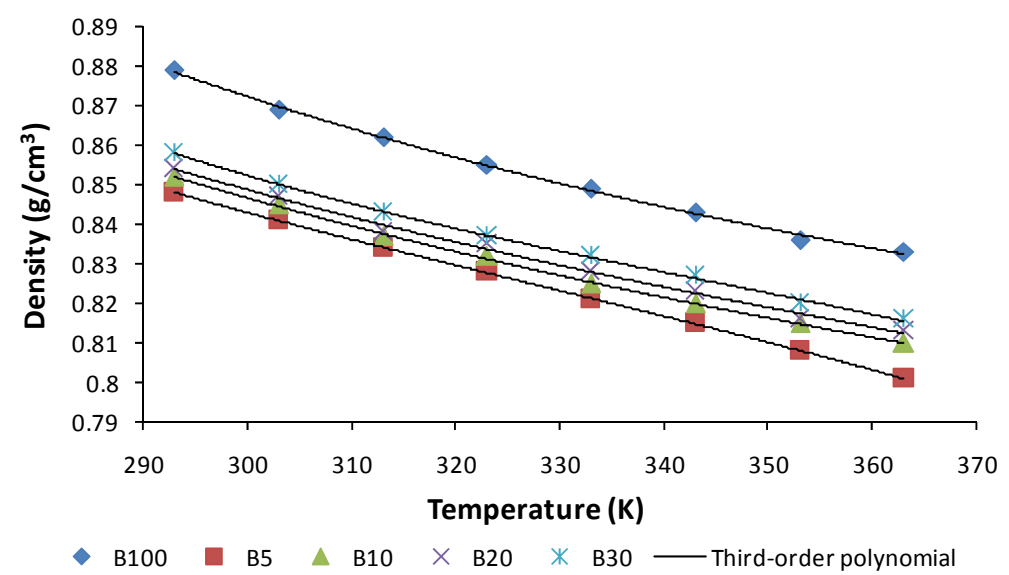

Figure 5. Effect of temperature on the densities of binary blends of soy biodiesel with petroleum diesel oil at different volume fractions. 


\subsection{Prediction of the Viscosities and Densities of Blends Determined by Correlation}

To predict the viscosities and densities of binary and ternary blends of soybeans oil, soy biodiesel and petroleum diesel at different temperature the correlation between viscosity and temperature and density and temperature were determined as shown in Figures $\mathbf{1}$ to $\mathbf{6}$ and the corresponding equations are presented in Tables $\mathbf{3}$ and $\mathbf{4}$, respectively. The best correlation between viscosity and temperature as well as between density and temperature for each of the binary and ternary blends was obtained by a third-order polynomial equations; respectively. The equation can generally be written as:

$$
N=A+B T+C T^{2}+D T^{3}
$$

where $N$ is either viscosity or density, $A, B, C$ and $D$ are constants and $\mathrm{T}$ is temperature $(K)$.

\section{Conclusion}

It can be concluded from the result of the present study that, the binary and ternary blends show temperature dependent behaviors. The densities and viscosities of binary and ternary blends decreased non-linearly with temperature, respectively. Accurate evaluation of the variations in viscosities and densities of the blends with respect to temperature, done by correlation showed that the polynomial equation correlates very well the variation of density and viscosity with temperature. The densities and viscosities of ternary blends and the binary blends of soy-biodiesel and petroleum diesel fall within

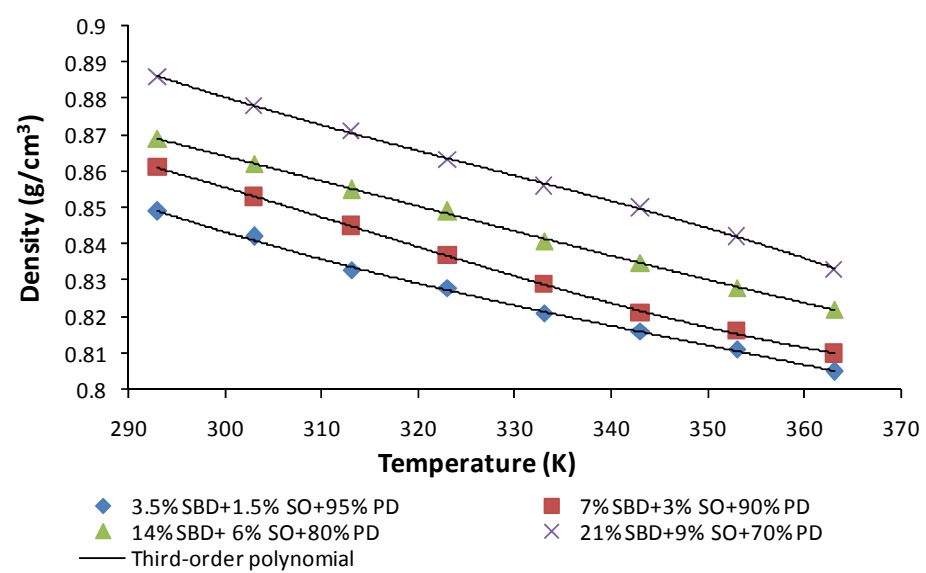

Figure 6. Effect of temperature on densities of ternary blends of soy biodiesel with soybean oil and petroleum diesel oil at different volume fractions.

Table 3. Correlation equation to predict the viscosity of binary and ternary blends at different temperature for different percentage volume of mixtures.

\begin{tabular}{|c|c|c|}
\hline \% Volume of Mixture & Third-Order Polynomial Equation & $\left(\mathrm{R}^{2}\right)$ \\
\hline P100 & $\mathrm{Y}_{1}=1 \mathrm{E} 10^{-6} \mathrm{x}^{3}-0.001 \mathrm{x}^{2}+0.144 \mathrm{x}+10.56$ & 0.996 \\
\hline $95 \% \mathrm{PD}+5 \% \mathrm{SO}$ & $\mathrm{Y}_{1}=-1 \mathrm{E} 10^{-5} \mathrm{x}^{3}+0.010 \mathrm{x}^{2}-3.619 \mathrm{x}+425.4$ & 0.986 \\
\hline $90 \% \mathrm{PD}+10 \% \mathrm{SO}$ & $Y_{1}=-8 E 10^{-6} x^{3}+0.008 x^{2}-2.808 x+332.3$ & 0.990 \\
\hline $80 \% \mathrm{PD}+20 \% \mathrm{SO}$ & $Y_{1}=-8 E 10^{-6} x^{3}+0.009 x^{2}-3.339 x+414.8$ & 0.996 \\
\hline $70 \% \mathrm{PD}+30 \% \mathrm{SO}$ & $\mathrm{Y}_{1}=7 \mathrm{E} 10^{-6} \mathrm{x}^{3}-0.006 \mathrm{x}^{2}-2.065 \mathrm{x}+198.8$ & 0.996 \\
\hline B100 & $Y_{1}=1 E 10^{-5} x^{3}-0.010 x^{2}+3.160 x-303.6$ & 0.985 \\
\hline B5 & $Y_{1}=6 E 10^{-6} x^{3}-0.005 x^{2}+1.410 x-122.3$ & 0.997 \\
\hline B10 & $\mathrm{Y}_{1}=7 \mathrm{E} 10^{-6} \mathrm{x}^{3}-0.006 \mathrm{x}^{2}+1.873 \mathrm{x}-177.5$ & 0.999 \\
\hline B20 & $Y_{1}=6 \mathrm{E} 10^{-6} \mathrm{x}^{3}-0.006 \mathrm{x}^{2}+1.797 \mathrm{x}-170.4$ & 0.996 \\
\hline B30 & $Y_{1}=1 E 10^{-5} x^{3}-0.012 x^{2}+3.847 x-393.0$ & 0.997 \\
\hline $95 \% \mathrm{PD}+3.5 \% \mathrm{SBD}+1.5 \% \mathrm{SO}$ & $Y_{1}=9 E 10^{-7} x^{3}-0.000 x^{2}+0.053 x+18.30$ & 0.995 \\
\hline $90 \% \mathrm{PD}+7 \% \mathrm{SBD}+3 \% \mathrm{SO}$ & $\mathrm{Y}_{1}=8 \mathrm{E} 10^{-8} \mathrm{x}^{3}+0.000 \mathrm{x}^{2}-0.201 \mathrm{x}+44.90$ & 0.994 \\
\hline $80 \% \mathrm{PD}+14 \% \mathrm{SBD}+6 \% \mathrm{SO}$ & $Y_{1}=1 E 10^{-6} x^{3}-0.000 x^{2}-0.127 x+9.387$ & 0.995 \\
\hline $70 \% \mathrm{PD}+21 \% \mathrm{SBD}+9 \% \mathrm{SO}$ & $Y_{1}=6 E 10^{-7} x^{3}-0.000 x^{2}-0.055 x+30.15$ & 0.992 \\
\hline
\end{tabular}

Where $\mathrm{Y}_{1}=$ Dynamic viscosity (mpa.s) and $\mathrm{x}=$ Temperature $(\mathrm{K})$. 
Table 4. Correlation equation to predict the density of binary and ternary blends at different temperature for different percentage volume of mixtures.

\begin{tabular}{|c|c|c|}
\hline$\%$ Volume of Mixture & Third-Order Polynomial Equation & $\left(\mathrm{R}^{2}\right)$ \\
\hline $\mathrm{P} 100$ & $Y_{2}=1 E 10^{-8} x^{3}-1 E 10^{-5} x^{2}+0.003 x+0.645$ & 0.999 \\
\hline $95 \% \mathrm{PD}+5 \% \mathrm{SO}$ & $Y_{2}=6 E 10^{-8} x^{3}-6 E 10^{-5} x^{2}+0.017 x-0.786$ & 0.997 \\
\hline $90 \% \mathrm{PD}+10 \% \mathrm{SO}$ & $Y_{2}=0.000 x^{3}+2 E 10^{-6} x^{2}-0.002 x+1.268$ & 0.998 \\
\hline $80 \% \mathrm{PD}+20 \% \mathrm{SO}$ & $Y_{2}=5 E 10^{-8} x^{3}-5 E 10^{-5} x^{2}+0.014 x-0.534$ & 0.997 \\
\hline $70 \% \mathrm{PD}+30 \% \mathrm{SO}$ & $Y_{2}=1 E 10^{-8} x^{3}-1 E 10^{-5} x^{2}+0.001 x+0.870$ & 0.992 \\
\hline B100 & $Y_{2}=-2 E 10^{-8} x^{3}+2 E 10^{-5} x^{2}-0.007 x+1.942$ & 0.998 \\
\hline B5 & $Y_{2}=-3 E 10^{-8} x^{3}+2 E 10^{-5} x^{2}-0.008 x+1.925$ & 1.000 \\
\hline B10 & $Y_{2}=-1 E 10^{-8} x^{3}+1 E 10^{-5} x^{2}-0.005 x+1.621$ & 0.999 \\
\hline B20 & $Y_{2}=-2 E 10^{-8} x^{3}+2 E 10^{-5} x^{2}-0.006 x+1.771$ & 0.994 \\
\hline B30 & $\mathrm{Y}_{2}=-4 \mathrm{E} 10^{-8} \mathrm{x}^{3}+4 \mathrm{E} 10^{-5} \mathrm{x}^{2}-0.015 \mathrm{x}+2.741$ & 0.998 \\
\hline $95 \% \mathrm{PD}+3.5 \% \mathrm{SBD}+1.5 \% \mathrm{SO}$ & $Y_{2}=-3 E 10^{-8} x^{3}+3 E 10^{-5} x^{2}-0.012 x+2.426$ & 0.998 \\
\hline $90 \% \mathrm{PD}+7 \% \mathrm{SBD}+3 \% \mathrm{SO}$ & $Y_{2}=5 E 10^{-8} x^{3}-5 E 10^{-5} x^{2}+0.014 x-0.447$ & 0.999 \\
\hline $80 \% \mathrm{PD}+14 \% \mathrm{SBD}+6 \% \mathrm{SO}$ & $Y_{2}=1 E 10^{-8} x^{3}-1 E 10^{-5} x^{2}+0.003 x+0.669$ & 0.999 \\
\hline $70 \% \mathrm{PD}+21 \% \mathrm{SBD}+9 \% \mathrm{SO}$ & $Y_{2}=-6 E 10^{-8} x^{3}+6 E 10^{-5} x^{2}+0.019 x+3.102$ & 0.999 \\
\hline
\end{tabular}

Where $\mathrm{Y}_{2}=$ Density $\left(\mathrm{g} / \mathrm{cm}^{3}\right)$ and $\mathrm{x}=$ Temperature $(\mathrm{K})$

the range limit of international standard for petroleum diesel and biodiesel. This means that ternary blends of vegetable oils, diesel fuels and biodiesel can be used in diesel engines when the right proportion are blended to give the density and viscosity at which the diesel engine can function effectively. Further investigation to practically test ternary blends on diesel engines is presently being carried out in our laboratory to ascertain its usefulness and acceptability in the world market.

\section{REFERENCES}

[1] H. Fukuda, A. Kando and H. Noda, "Biodiesel Fuel Production by Transesterification of Oils," Journal of Bioscience and Bioengineering, Vol. 92, No. 5, 2001, pp. 405-416.

[2] C. L. Peterson, R. O. Cruz, L. Perkings, R. Korus and D. L. Auld, "Transesterification of Vegetable Oil for Use as a Diesel Fuel: A Progress Report,” ASAE Paper NO. PNWS90-610, American Society of Agricultural Engineers (ASAE), St. Joseph, 1990.

[3] Y. Z. Wang, T. Shemmeri, P. Earnes, J. McMullan, N. Hewitt and Y. Huang, "An Experimental Investigation of the Performance and Gaseous Exhaust Emission of a Diesel Engine Using Blends of a Vegetable Oil,” Applied Thermal Engineering, Vol. 26, No. 14-15, 2006, pp. 16841691. doi:10.1016/j.applthermaleng.2005.11.013

[4] A. C. Pinto, L. N. G. Lilian, J. C. R. Michelle, M. R. Nubia, A. T. Ednildo, A. L. Wilson, A. de P. P. Pedro and B. de A. Jailson, "Biodiesel: An Overview," Journal of the Brazilian Chemical Society, Vol. 16, No. 6b, 2005, pp. 1313-1330. doi:10.1590/S0103-50532005000800003

[5] O. J. Alamu, M. A. Waheed and S. O. Jekayinfa, “AlkaliCatalysed Laboratory Production and Testing of Bio- diesel from Nigerian Palm Kernel Oil,” Agricultural International: CIGR Electonic Journal, Vol. IX, 2007, pp. 1-10.

[6] S. C. A. de Almeida, C. R. Belchoir, M. V. G. Nascimento, L. dos S. R. Vieira and G. Fluery, "Performance of a Diesel Generator Fuelled with Palm Oil,” Fuel, Vol. 81, No. 16, 2000, pp. 2097-2102.

[7] M. I. Zubir and S. Y. Chin, "Kinetics of Modified Zirconia-Catalyzed Heterogeneous Esterification Reaction for Biodiesel Production,” Journal of Applied Science, Vol. 10, No. 21, 2010, pp. 2584-2589. doi:10.3923/jas.2010.2584.2589

[8] U. Schuchardt, R. Sercheli and R. M. Vargas, "Transesterification of Vegetable Oils: A Review," Journal of Brazilian Chemical Society, Vol. 9, No. 3, 1998, pp. 199210. doi:10.1590/S0103-50531998000300002

[9] B. K. Barnwal and M. P. Sharma, "Prospects of Biodiesel Production from Vegetable Oils in India," Renewable and Sustainable Energy Reviews, Vol. 9, No. 4, 2005, pp. 363378. doi:10.1016/j.rser.2004.05.007

[10] L. Meher, S. Vidya and S. Naik, "Technical Aspects of Biodiesel Production by Transesterification-A Review," Renewable and Sustainable Energy Reviews, Vol. 10, No. 3, 2006, pp. 248-268. doi:10.1016/j.rser.2004.09.002

[11] A. R. Srivastava and R. Prasad, "Triglycerides-Based Diesel Fuels," Renewable and Sustainable Energy Reviews, Vol. 4, No. 2, 2000, pp. 111-133. doi:10.1016/S1364-0321(99)00013-1

[12] U. Rashid and F. Anwar "Production of Biodiesel through Optimized Alkaline-Catalyzed Transesterification of Rapeseed Oil,” Fuel, Vol. 87, No. 3, 2008, pp. 265-273.

[13] N. Jaya and K. Etihbrajulu, "Kinetic Modelling of Transesterification Reaction for Biodiesel Production Using Heterogeneous Catalyst,” International Journal of Engineering, Science and Technology, Vol. 3, No. 4, 2011, pp. 
3463-3466.

[14] Y. Shimada, H. Watanabe, A. Sugihara and Y. Tominaga, "Enzymatic Alcoholysis for Biodiesel Fuel Production and Application of the Reaction to Oil Processing," Journal of Molecular Catalysis B: Enzyme, Vol. 17, No. 3-5, 2002, pp. 133-142. doi:10.1016/S1381-1177(02)00020-6

[15] Y. Zhang, M. A. Dube, D. D. Mclean and M. Kates, "Biodiesel Production from Waste Cooking Oil: 1. Process Design and Technological Assessment,” Bioresource Technology, Vol. 89, No. 1, 2003, pp. 1-16. doi:10.1016/S0960-8524(03)00040-3

[16] D. Royon, M. Daz, G. Ellenrieder and S. Locatelli, “Enzymatic Production of Biodiesel from Cotton Seed Oil Using $t$-Butanol as a Solvent,” Bioresource Technology, Vol. 98, No. 3, 2007, pp. 648-653. doi:10.1016/j.biortech.2006.02.021

[17] A. Demirbas, "Biodiesel Fuels from Vegetable Oils via Catalytic and Noncatalytic Supercritical Alcohol Transesterification and Other Methods: A Survey," Energy Conversion and Management, Vol. 44, No. 13, 2003, pp. 2093-2109. doi:10.1016/S0196-8904(02)00234-0

[18] R. D. Abigor, P. O. Uadia,T. A. Foglia, M. J. Hasa, K. C. Jones, E. Okpefa, J. U. Obibuzor and M. E. Bafor, "Lipase Catalysed Production of Biodiesel Fuel from Some Nigerian Lauric Oils,” Biochemical Society Transactions, Vol. 28, No. 6, 2000, pp. 979-981. doi:10.1042/BST0280979

[19] Y. Watanabe, Y. Shimada, A. Sugihara and Y. Tominaga, "Conversion of Degummed Soybean Oil to Biodiesel Fuel with Immobilized Candida antarctica Lipase,” Journal of Molecular Catalysis B: Enzyme, Vol. 17, No. 3-5, 2002, pp. 151-155. doi:10.1016/S1381-1177(02)00022-X

[20] O. Kose, M. Tuter and H. A. Akosoy, "Immobilized Candida antarctica Lipase-Catalysed Alcoholysis of Cotton Seed Oil in a Solvent-Free Medium,” Bioresource Technology, Vol. 83, No. 2, 2002, pp. 125-129. doi:10.1016/S0960-8524(01)00203-6

[21] S. Dmytoyshyn, A. Dalai, S. Chandhari, H. Mishra and M. Reaney, "Synthesis and Characterization of Vegetable Oil Derived Esters: Evaluation for Their Diesel Additional Properties,” Bioresource Technology, Vol. 92, No. 1, 2004, pp. 55-64. doi:10.1016/j.biortech.2003.07.009,

[22] S. E. Agarry, A. O. Ajani, O. A. Aworanti and B. O. Solomon, "Alkali Catalyzed Production of Biodiesel Fuel from Nigerian Citrus Seeds Oil,” Proceedings of the 40th Annual Conference of Nigerian Society of Chemical Engineers, Harnessing and Optimizing Nigeria's Energy Resources in the New Decade, Port Harcourt, 16-18 No- vember 2010, pp. 145-155.

[23] O. O. Fasina and Z. Colley, "Viscosity and Specific Heat of Vegetable Oils as a Function of Temperature: $35^{\circ} \mathrm{C}$ to $180^{\circ} \mathrm{C}$," International Journal of Food Properties, Vol. 11, No. 4, 2008, pp. 738-746. doi:10.1080/10942910701586273

[24] M. Dak, R. C. Verma and M. K. Jain, "Mathematical Models for Prediction of Heological Parameters of Pineapple Juice," International Journal Food Engineering, Vol. 4, No. 3, 2008, pp. 1-17. doi:10.2202/1556-3758.1285

[25] I. Stanciu, “A New Viscosity-Temperature Relationship for Vegetable Oil,” Journal of Petroleum Technology and Alternative Fuels, Vol. 3, No. 2, 2012, pp. 19-23.

[26] J. Toth, Z. Simon, P. Medveczky, L. Gombos, B. Jelinek, L. Szilagyi, L. Graf and A. Malnasi-Csizmadia, "Site Directed Mutagenesis at Position 193 of Human Trypsin 4 Alters the Rate of Conformational Change during Activation: Role of Local Internal Viscosity in Protein Dynamics," Structural Functional Genetics, Vol. 67, No. 4, 2004, pp. 1119-1127. doi:10.1002/prot.21398

[27] C. Kapseu, G. J. Kayem, D. Balesdent and L. Schuffenecker, "Estimation of Dynamic Viscosities of Vegetable Oils," Journal of American Oil Chemical Society, Vol. 68, No. 2, 1991, pp. 128-133. doi:10.1007/BF02662333

[28] W. Lang, S. Sokhansanj and F. W. Sosulski, "Modelling the Temperature Dependence of Kinematic Viscosity for Refined Canola Oil,” Journal of American Oil Chemical Society, Vol. 69, No. 10, 1992, pp. 1054-1062. doi:10.1007/BF02541080

[29] J. F. Toro-Vazquez and R. Infante-Guerrero, "Regressional Models That Describe oil Absolute Viscosity," Journal of American Oil Chemical Society, Vol. 70, No. 11, 1993, pp. 1115-1122. doi:10.1007/BF02632152

[30] M. Ahmad, S. Rashid, M. A. Khan, M. Zafar, S. Sultana and S. Gulzar, "Optimization of Base Catalysed Transesterification of Peanut Oil Biodiesel," African Journal of Biotechnology, Vol. 8, No. 3, 2009, pp. 441-446.

[31] Z. J. Predojevic and B. D. Skrbic, “Alkali Catalysed Production of Biodiesel from Waste Frying Oil," Journal of Serbian Chemical Society, Vol. 74, No. 8-9, 2009, pp. 993-1007. doi:10.2298/JSC0909993P

[32] E. A. Ajav and O. A. Akingbehin, "A Study of Some Fuel Properties of Local Ethanol Blended with Diesel Fuel," Agricultural Engineering International: The CIGR Journal of Scientific Research and Development, Vol. IV, 2002, pp. 1-9. 